\title{
Participation, politics, and panaceas: exploring the possibilities and limits of participatory urban water governance in Accra, Ghana
}

\author{
Cynthia Morinville $^{1}$ and Leila M. Harris ${ }^{1}$
}

\begin{abstract}
Water governance debates have increasingly recognized the importance of adaptive governance for short- and long-term sustainability, especially with respect to increasing climate unpredictability and growing urbanization. A parallel focus on enhancing community participation pervades international development recommendations and policy literature. Indeed, there are often implicit and explicit connections made between the participatory character of water governance institutions and their adaptive capacity. The social-ecological systems literature, however, has also urged caution with respect to embracing panaceas, with increasing calls to be attentive to the limitations of proposed "solutions." We discuss the parallels between the adaptive governance, comanagement, and participatory resource governance literatures and analyze efforts to encourage such participation in urban water governance through Local Water Boards in Accra, Ghana. Drawing on interview data, participant observations, and a survey of 243 individuals, we explored what participatory spaces have been opened or foreclosed as well as the possibilities for adaptive urban water governance in Accra. Applying insights from recent debates about panaceas, we argue that discerning the potential and limits for sustainable resource governance and associated development goals requires that participatory mechanisms be subjected to systematic and contextual analysis.
\end{abstract}

Key Words: adaptive governance; Ghana; Local Water Boards; participatory governance; water governance

\section{INTRODUCTION}

Increasing population, urbanization, and climate variation present cities with a number of water governance challenges. Adaptive water governance is often presented as an approach to more effectively and equitably meet human and ecosystem needs in the face of hydrologic change and uncertainty (Huntjens et al. 2011, Pahl-Wostl et al. 2012). In the global South, these approaches intersect with a strong focus on participatory governance institutions in both water governance and international development recommendations. We explore the relationship between these parallel and convergent trends of adaptive capacity and participatory governance. In our case study of underserved settlements in Accra, Ghana, we also consider the potential to deliver on the promise of adaptable and inclusive institutions and governance systems, as well as extended water access. Beginning with some theoretical discussion, we then offer an empirical examination of these approaches through a case study of the Local Water Boards (LWBs) recently established in several communities of Accra, Ghana. Like many urban areas of the global South, Accra is part of a functioning democracy but faces considerable poverty levels, inadequate infrastructure, and ongoing challenges related to both extending water access and fostering more inclusive governance. At present, approximately half of the Greater Accra Metropolitan Area (GAMA) is served by a piped system administered by the municipal public utility, Ghana Water Company Limited (GWCL; Ainuson 2010, Adank et al. 2011). Although this article considers some of the challenges associated with extending access to water and sanitation services in underserved areas of Accra, the primary focus is on current efforts to promote participation, most notably through LWBs, and the implications for adaptive and participatory water governance.

We review the relevant literature on adaptive governance, participation, and panaceas. We then present a detailed discussion of our case study's context and methodology. We analyze results and argue that although LWBs are promising mechanisms to promote greater participation in urban water governance in Accra, and perhaps other cities in the global South facing similar challenges, significant limitations remain. Such mechanisms should therefore be subjected to close scrutiny and thoughtful evaluation rather than treated as a panacea.

\section{CONVERGING APPROACHES: ADAPTIVE AND PARTICIPATORY WATER GOVERNANCE}

Adaptive governance and social-ecological systems

The concept of adaptive governance, including adaptive water governance, draws on debates in natural resource management generally and adaptive management and comanagement in particular (Dietz et al. 2003, Olsson et al. 2004, Nadasdy 2007). Governance, as opposed to management, refers to how decisions are made and by whom; adaptive governance thus aims to address the complexity and nonequilibristic character of ecosystems through governance processes that foster dynamic learning and iterative feedback by constantly reassessing decision making and outcomes (Lee 1999, Olsson et al. 2004, 2006). Management actions are considered as ongoing experiments that can test hypotheses about expected results and therefore seen as an opportunity and imperative to learn and modify approaches (Folke et al. 2005). This approach has been bolstered both by a growing appreciation of the inadequacy of top-down approaches to resource management and an enriched understanding of the complexity of human and ecological systems. Building on the field of social-ecological systems, which highlights the interdependence, complexity, and uncertainty of social and environmental systems, adaptive governance also focuses on extending ecosystem and resilience concepts to include a "human dimension" as well as on the need to adopt a "systems thinking" approach to achieve resilience (Holling 1978, Holling and Meffe 1996). Linked to adaptive governance, the comanagement approach also aims to move beyond top-down decision making and include the input of local populations. As summarized by Folke et al. (2005:448), comanagement "relies on the 
collaboration of a diverse set of stakeholders, operating at different levels, often through networks from local users to municipalities, to regional and national organizations, and also to international bodies" (see also Olsson et al. 2004). Together, these approaches have been termed "adaptive co-management" (Olsson et al. 2004), which represents a convergence of thought around participatory and adaptive institutions and governance practices as key to fostering greater effectiveness and equity in resource governance and to avoid problems emerging from a lack of direct engagement with affected populations, which can lead to inadequate monitoring, scalar mismatches, and failures attributable to contextually inappropriate or one-size-fits-all approaches (see Ostrom 1990, Cumming et al. 2006).

Complementary concepts sharing an implicit focus on collaboration between different actors and across scales include polycentricity, the necessity of multiple decision centers; multiscalar approaches, nesting these units at multiple scales, particularly to avoid "scalar mismatches"; and social learning, the experimental design of management adopting a "learning-bydoing" approach (Folke et al. 2002, 2005, Berkes et al. 2003, Gunderson et al. 2006, Lebel et al. 2006, Huitema et al. 2009, Pahl-Wostl 2009, Pahl-Wostl et al. 2011, Bakker and Morinville 2013). Arguably, the need to engage local actors also inheres in these related concepts. For instance, the threat of scalar mismatches is heightened when actors are not engaged in governance processes across scales. This can lead to processes or decisions at a particular scale that do not scale up or scale down and may not secure a buy-in from all relevant actors. Moreover, as Ostrom's (1990) exploration of common pool resource governance clearly demonstrates, failure to engage local actors frequently results in inadequate monitoring, ineffective governance, and poor outcomes. These multiple approaches demonstrate a strong imperative, both explicit and implicit, for participation. The international development and water governance literatures, to which we turn next, echo this participatory imperative with a similar focus on effective governance in addition to considerations such as equity (Agarwal 2001, 2010).

\section{Participatory water governance and international development perspectives}

Since the 1980s, participatory governance has evolved into a mainstream discourse in international development theory and practice (Hickey and Mohan 2004), as well as in the realms of water governance (Harris et al. 2013) and conservation (Nadasdy 2005). As noted previously, these perspectives parallel many of the insights of adaptive governance approaches, although the latter have tended to focus mainly on North American, European, and industrialized contexts (McLain and Lee 1996, Olsson et al. 2004, Nadasdy 2005, Armitage et al. 2008, 2011). International development literatures, as with adaptive comanagement scholarship, often present participation as central to overcoming the disjuncture between top-down policies and localities, improving outcomes by applying local knowledges, e.g., for poverty alleviation (Ahmad 2003), or leading to more effective monitoring by directly involving communities in rule establishment and enforcement (Ostrom 1990). Furthermore, participation and community-based planning are increasingly considered as crucial components of climate change adaptation programs aiming to foster better preparedness and thus resilience for vulnerable communities (Lim et al. 2004, Tompkins and Adger 2004, Few et al. 2007, Westerhoff and Smit 2009). Several noteworthy international agreements, including the Aarhus Convention on Participatory Management for Environmental Matters (UNECE 1998), the Dublin Principles (1992), and the Bonn Recommendations for Action (Secretariat of the International Conference on Freshwater 2001), reiterate the suggestion that policies regarding water be developed on the basis of consultations with those affected; the latter two agreements offer recommendations specific to water issues (see also Goldin 2013 for a discussion of participatory water governance). Proponents have also argued that, in addition to ensuring effective natural resource management, participatory processes are a way of fostering equity and community empowerment, including among women and other marginalized members of society (Schreiner et al. 2004).

\section{Power, politics, and panacea}

Despite such diverse and frequent calls for participation, the empirical evidence with respect to its manifold putative benefits remains ambivalent (Cleaver 2001, Cooke and Kothari 2001, Hickey and Mohan 2004). Although some case studies document the advantages of participatory and deliberative governance processes (e.g., Lebel et al. 2006), others demonstrate the many ways in which participation instead often falls short of realizing stated social and environmental objectives (e.g., O'Reilly and Dhanju 2012). Participatory approaches have performed particularly poorly with respect to community empowerment goals; supportive evidence is both thin (Parkes et al. 2010) and disputed by documentation across a range of contexts suggesting that communities may be further marginalized by participationreliant governance processes (e.g., Agarwal 2001). Although the participatory governance literature has paid increasing attention to issues of social power (Cooke and Kothari 2001, Hickey and Mohan 2004, Nadasdy 2005), the adaptive comanagement literature has focused relatively less on these questions, as summarized previously (for promising discussions, see Nadasdy 2003, Kofinas 2005, Spaeder 2005, Armitage 2008, Pahl-Wostl 2009, Pahl-Wostl et al. 2011, Bakker and Morinville 2013). We suggest that more careful and critical assessments of participation and social power are warranted for adaptive governance, social learning, and parallel discussions aligned more closely with socialecological systems debates. As we detail subsequently, mandating participation without sufficient attention to the influences of social context, power dynamics, and politics risks creating what Ostrom and Cox (2010:452) have described as a panacea problem (see also Ostrom 2007, Pahl-Wostl et al. 2012):

The panacea problem occurs whenever a single presumed
solution is applied to a wide range of problems. This
problem has two distinct dimensions. The first dimension
occurs in situations where a theory is too precise to be
flexibly adapted to the range of cases to which it is applied
[also know as a blueprint approach to governance]. The
other dimension involves theories that are excessively
vague instead of excessively precise.

We suggest that adaptive governance perspectives, with their implicit focus on participation as described previously, might 
therefore benefit from the critical perspectives on participatory approaches outlined in international development and water governance, and conservation literatures, if they are to avoid such panacea problem. We review these critiques before moving on to our case study of Accra's LWBs.

\section{Critical perspectives on participation}

An increasing body of critical work has called participation into question, charging that the concept of "community" is too often romanticized (Cleaver 2001), that preoccupation with the "local" overlooks the multiscalar (re)production of power relations, and that participation has emerged as "hegemonic" in ways that potentially sideline discussions of alternatives (Harris et al. 2013). It is also suggested that participatory approaches may result in a burdensome "devolution" of responsibility to vulnerable communities (see Walker 1999, Ribot 2002, Kesby 2005); considering the significant capacity, time, and resource requirements, tasking marginalized groups with solving water governance challenges may be inappropriate (Harris 2009). Many scholars accordingly express concerns about the potential of participatory governance to entrench power dynamics, usher in new modes of governmentality, or perpetuate inequalities (Agarwal 2001, Cooke and Kothari 2001, Ribot 2002, Harris 2005, 2009, Kesby 2005, Goldin 2010). Moreover, an emphasis on "formal" participation oftentimes values concrete and countable issues like meeting attendance over less tangible questions such as the quality or equity dimensions of participation, particularly with attention to gender, caste, class, race, and so forth (see Agarwal 2001, Barnes 2013, Morales and Harris, in press), in addition to neglecting participation that may occur outside of formally recognized spaces. ${ }^{[1]}$ Power dynamics, as necessary corollaries of empowerment, must therefore be highlighted in scholarship concerned with the roles of formal and informal processes in fostering or constraining meaningful participation (Agarwal 2001, Zwarteveen et al. 2010, Barnes 2013, Morales and Harris, in press). O'Reilly and Dhanju (2012:627) write that "when participatory approaches do not engage with everyday power dynamics, either among citizens, or between citizens and the state - they become technical routines or simply a discourse applied without commitment to political change." All of these insights, we suggest, offer openings for productive discussions in the adaptive governance and comanagement literatures, as well as a point of departure for our case study of LWBs in urban Accra, Ghana.

\section{CASE STUDY}

This study is part of a broader comparative and collaborative project on water access and participatory governance in informal and underserved settlements of Accra, Ghana, and Cape Town, South Africa (EDGES [Environment and Development: Gender, Equity, Sustainability], http://www.edges.ubc.ca). The research we present is specifically concerned with the implementation of LWBs in several underserved areas of Accra as an approach to participatory water governance. As with most other contexts, water governance in Accra includes a strong focus on participatory approaches; calls for participation are found across multiple scales and institutions, including the World Bank, the Government of Ghana, the municipality of Accra, as well as among nongovernmental organizations (NGOs) that operate in the communities studied. The World Bank (2014), for instance, clearly states that "participation and civic engagement" is a primary theme of its Urban Water Project in Ghana. Cooperative Housing Foundation International Ghana (http://www. chfinternationalghana.org/), hereafter CHF, an NGO operating in Accra, ${ }^{[2]}$ also maintains: "Using a community-driven approach that involves residents and a broad range of stakeholders, CHF is helping to improve availability and access to water and sanitation services." Accra accordingly presents an interesting case to consider the potential and limits of participatory water governance, offering insights that may also be relevant for other contexts in the global South and across the globe.

\section{Context}

Ghana's capital city, Accra, is a fast-growing, coastal urban center facing considerable planning challenges, including a population expected to increase more than twofold in the coming decade (Government of Ghana 2011) and the uncertain impacts of climate change (Douglas et al. 2008). The GWCL is the main provider of drinking water in the GAMA. Estimates regarding water access across Accra vary considerably; one source reports that, in 2010, 59\% of households in Accra had a connection (Ghana News Agency, cited in Ainuson 2010), and another suggests that $51 \%$ of the population in GAMA has direct access to the municipal utility water supply (Adank et al. 2011). For Ghana nationally, another source states that $91 \%$ of urban residents, including but not limited to residents of Accra, have access to improved drinking water, ${ }^{[3]}$ but only $32 \%$ of residents have their own connection (WHO/UNICEF 2012). The system is also commonly reported to suffer shortfalls between demand and supply. In response, GWCL relies on a rationing schedule to manually isolate certain neighborhoods and direct water to other areas of the city on certain days. Certain neighborhoods are scheduled to receive water seven days a week, whereas others are only scheduled to have access once per week. Intermittent supply is also reportedly common apart from the rationing schedule, meaning that some households receive water only for a couple of hours even on days with scheduled service. Thus, even with $\sim 50 \%$ coverage, it is estimated that only $25 \%$ of Accra's residents have continuous water access (Ainuson 2010). Unconnected households and those affected by shortages often rely on secondary and tertiary providers, e.g., tanker services, water vendors or kiosks, and sachet or bottled water, providers who often obtain their water directly from GWCL and then sell it for a profit. It is notable that some of these sources would qualify as "improved water sources," thus helping to explain the $91 \%$ estimate cited previously (see footnote 3). As we discuss subsequently, in the communities investigated, several of these modes of access, e.g., water tanks used by vendors, may be mediated by NGOs or community entities such as LWBs.

\section{Methodology}

Five communities were involved with this study, detailed in Communities investigated. The case study is based on a mixedmethods approach, including both quantitative and qualitative data collection. Specifically, the data we mobilize draw from (1) a series of 43 qualitative, in-depth semistructured and expert interviews; (2) participant observations at community meetings and events; and (3) a quantitative survey of 243 individuals, conducted in 2 communities of urban Accra.

In-depth semistructured interviews were conducted with community members/residents, selected through a snowball sampling method, and members of LWBs during 2011-2012 in 4 
Table 1. Communities investigated.

\begin{tabular}{ll}
\hline \hline Community & Description \\
\hline Teshie & Indigenous community. \\
& Older coastal settlement. \\
& Serious water shortages: the two mains supplying Accra near their end as they reach the community. \\
Ashaiman & Recently established in-migrant community. \\
& Peri-urban location on the northeast outskirts of GAMA. \\
& Connectivity maps and information provided by GWCL suggest that the community should have relatively good access to the \\
& piped network given its proximity to the Tema reservoir. \\
& Many households cannot afford the high connection fees and monthly invoices. \\
Nima & Often cited as Accra's largest slum with particularly poor infrastructure and acute poverty. \\
& Largely connected to GWCL's piped water network. \\
& Subjected to rationing that reduces services to two to three days/week. \\
& High elevation results in water shortages due to low system pressure. \\
Ayidiki & Considerable recent in-migration and population growth. \\
& Middle-level elevation renders the settlement prone to pressure-related shortages. \\
& Piped network reaches the settlement but connectivity remains limited. \\
Sukura & Lack of infrastructure results in water availability issues. \\
& Lower elevation. \\
& Most favorable situation in terms of water access among our study sites. \\
& Settlement often characterized as precarious in terms of infrastructure and poverty.
\end{tabular}

underserved communities of GAMA: Teshie, Nima, Ayidiki, and Sukura. LWBs were functioning in the first 3 communities, with none in place in Sukura. Inclusion of communities without LWBs is part of our broader research effort on water access and governance in GAMA and allows us to consider questions of interest with respect to the effectiveness of the LWBs, as well as possibilities for participatory governance in instances where such formal institutions do not exist. Although an in-depth evaluation of other participatory mechanisms and possibilities is beyond our scope, we include a brief discussion in Results and discussion (see also Peloso 2014). Expert interviews were also conducted with utility representatives, NGO staff, and government officials at the municipal level in 2011-2012.

In addition, data were gathered through participant observations at community meetings and events, including a 2012 community feedback session focused on the LWBs. The participants in this session included those sites we had studied with LWBs, as well as one additional community with an active LWB where we had not done previous research (Avenor). At this feedback session, we presented our results and solicited community responses and reactions. We provide a sense of the reactions at several points in the discussion that follows.

The quantitative survey was implemented in collaboration with local partners as part of a broader multiyear research project ${ }^{[4]}$ in 2012 in the communities of Teshie $(n=120)$ and Ashaiman $(n=$ 123). Although Teshie has a functioning LWB, Ashaiman does not. Again, the presence of an LWB in only 1 of the 2 communities allows for some comparisons, which we discuss, albeit briefly, in Results and discussion. The survey constitutes a secondary data set and is referred to throughout to contextualize the trends that were highlighted by the qualitative components of the study.

Although we draw on experiences of LWBs from several communities, we do not report our results in a comparative fashion but rather seek to identify the range of experiences with LWBs across Accra. Our focus on multiple communities, however, allows us to speak to the broader range of issues that might be at play in various LWBs. For the analysis, respondents' statements were coded and then organized by themes, informed by the literature presented in Converging approaches: adaptive and participatory water governance. For each theme presented in Results and discussion, we draw on a key example, vignette, or illustrative quote to demonstrate the range of issues relevant to the implementation of LWBs in these communities. Given our interest in speaking to the range of experiences, we aim to present a broad-ranging discussion and not necessarily to suggest that these trends are generalizable to all of Accra or all LWBs. However, whenever community or organizational dynamics do come across as less generalizable, and very specific to that context, we specify accordingly.

\section{Communities investigated}

All five communities investigated qualify as underserved areas when it comes to water provision and other basic services and correspond to the United Nations Human Settlements Programme (UN-HABITAT) definition of slums. ${ }^{[5]}$ We provide a brief overview of our study communities in Table 1 .

\section{Local water boards}

LWBs were initiated in 2007 and are currently operational across urban Accra, including in 3 of the communities investigated, i.e., Nima, Teshie, and Ayidiki. Although all boards share some general characteristics, they also differ considerably depending on the locality or the particular partners involved. LWBs generally include elected representatives from a number of "interest groups," e.g., women, youth, elders, and so forth, within a community for a total of 10 to 15 members. Teshie's water board was the first to be established by the utility company (GWCL) in 2007 as part of a propoor initiative (interview with GWCL official, 19 July 2011; interview with LWB member, 11 July 2011). The utility later established LWBs in 6 other communities of Accra, including Nima in 2008. CHF became involved with Nima's LWB in 2009. Targeting Nima and other communities 
based on the poor water and sanitation conditions, $\mathrm{CHF}$ went on to follow the model of Nima's LWB and established similar boards

${ }^{[6]}$ in 2 other communities of Accra, including Ayidiki in 2010, and 2 communities outside of Accra (interview with CHF, 13 July 2011). More recently, the Public Utility Regulatory Commission (PURC) also established boards in several communities of Accra as part of a pilot project, including 1 in Teshie.

Although a primary goal of the LWBs is to promote local participation, the boards are also, at times, responsible for the provision of a certain portion of the water in the community. For instance, the LWB in Teshie is responsible for the administration of a tanker as well as several water kiosks, including hiring a driver for the tanker and vendors for the kiosks. The tanker is filled at a provision point administered by GWCL where water is paid for up front by the LWB. The LWB in turn facilitates distribution of the water to vendors, who then sell it to community members at a fixed price established jointly by the board, GWCL, and PURC. Water kiosks in Nima and Ayidiki are slightly different than the ones found in Teshie. No tankers are involved, and the kiosks rely on a direct connection to the mains. Water is nonetheless stored in polytanks ${ }^{[7]}$ to avoid access problems associated with shortages or inconsistent delivery through the municipal network. GWCL again charges the board for the water, and the board employs vendors who sell it to community members at a fixed price. Nima's LWB, with the financial help of CHF, in turn funded by the United States Agency for International Development (USAID) and the Bill and Melinda Gates Foundation, will also add two boreholes to supply the community in times of shortage ${ }^{[8]}$ LWBs established in partnership with $\mathrm{CHF}$ also focus considerable effort on behavioral change related to sanitation. Furthermore, LWBs can also facilitate the process of getting a private connection to the network or a private latrine. Although the LWB mediates such activities, not everything goes through the organization, and not all water flowing through a community is administered by the LWB. For instance, individuals connected directly to the mains are not reliant on the extensions provided by the board, and many private vendor services also operate within these communities.

\section{RESULTS AND DISCUSSION}

We draw primarily from qualitative data gathered via interviews and participant observations to highlight, through residents' own words and vignettes, the possibilities and limits of participatory water governance in the form of LWBs currently operational within Accra. The results are organized according to themes that emerged through the qualitative data, as well as those identified in the participatory governance literature. In terms of the analysis, the themes highlighted speak both to the elements that were stressed as effective, or operating well, as well as those elements that were highlighted as being ineffective, inequitable, or in need of improvement with respect to participatory governance aims. Although not comprehensive, the subsequent themes and illustrations give us a sense of the degree to which LWBs contribute to effective or equitable water governance or meeting the objectives of participatory and adaptive governance in the communities investigated.

\section{Communication channel}

First, the LWBs can serve as a channel for communication between the community and the utility (GWCL). One LWB chairperson expressed, for instance, the sense that LWBs serve to communicate key challenges and needs of the community to the water utility:

There is a lot of collaboration because they know us, we also know them. They call us, we call them. We have meetings concerning water related programs in the community. So for instance, when they were doing the pipe laying they had to disconnect a particular group line and these community members came here to complain to us. I also called GWCL to lodge the complaint and they came and rectified it. (Interview with LWB chairperson, 14 July 2011).

This function appears critical considering GWCL's general absence in underserved communities. LWBs may therefore offer an opportunity to hold the utility or community accountable to one another. Community members interviewed also suggested that LWBs have become the go-to organization when issues regarding water arise. At the same time, data from the survey report that there is not a great deal of familiarity with water management entities, with $96 \%$ reporting no such committees exist, only 2 respondents $(<1 \%)$ reporting they would "go to an NGO" to raise concerns related to water, and $26 \%$ reporting they would "go to a local councilor or representative," in turn likely to be a member of the board. This suggests that LWBs may offer one avenue for residents to voice their concerns. Nonetheless, possibilities for broad community engagement appear to remain limited given that few survey respondents seem to be aware of the presence of entities such as LWBs in their communities.

Furthermore, a representative from the utility reported that communication with the community typically occurs after issues arise rather than through regular interactions. Communications remain reactionary, ad hoc, and rooted in specific problems (interview with utility representative, 19 July 2011). LWBs thus offer certain elements of adaptive governance institutions: a polycentric system nested at multiple scales. That being said, current challenges to effective communication present limits from a social learning perspective. If we consider that there needs to be regular and transparent communication between entities to build trust and share information for adaptive responses, the evidence on communication supports the argument that LWBs appear to have potential but face clear limitations at present.

\section{Extended access and fixed price for water}

LWBs, despite falling short of universal coverage by a large margin, also serve to extend water and sanitation access to underserved communities. Although this is in line with promised benefits, the schemes implemented also result in communities having to prepay for water infrastructure and services. ${ }^{[9]}$ This can help to overcome long-standing issues regarding nonrevenue water, estimated at $50 \%$ of current production in GAMA. However, it does little to alleviate affordability challenges that are significant for many residents of these areas; consider that $68 \%$ of survey respondents in Accra reported that they do not find water to be "affordable." At the same time, LWBs sell water at an established price, negotiated between the utility, vendors, and the different partner organizations, which can set expectations, and reduce potential stress associated with haggling prices on a daily basis for community members (see Wutich and Ragsdale 2008 for a broader discussion on stress and water access based on a Cochabamba, Bolivia, case study). 


\section{Infrastructural legacy}

Linked with extending water access to underserved communities, infrastructural development constitutes one of the main contributions and lasting impacts of LWBs for communities. For example, a partnership with a Dutch development organization resulted in the donation of a tanker to Teshie's LWB, helping the community to cope in times of shortages. In Nima, CHF funded the drilling of two boreholes supplementing water supply to the community. In Ayidiki, CHF contributed to laying down pipes across the area, thereby extending coverage. In many other cases, the LWBs and partner organizations installed large tanks to store water for times when the communities are subject to rationing or face other shortages. Generally funded by large donor agencies, such as USAID and the Bill and Melinda Gates Foundation, these partnerships also have the potential to bring tensions given the different development agendas of involved partners, as we discuss subsequently.

\section{Procedural nature of development}

The heavily procedural nature of water-related development in Accra presents further limits to LWBs' ability to extend water access or promote more learning and adaptive governance in underserved areas. Despite LWBs often facilitating the process of getting a new connection or building a permitted latrine for community members, as noted previously, the steps required for such development are considerable. The process generally involves the homeowner or household head, the LWB, the NGO, a microfinance organization, the utility, and the submetro, the local government responsible for sanctioning the development plans. The complex process may discourage participation and, in turn, limit LWBs' potential to broker improvements regarding water access or infrastructure in communities. An LWB member alluded to these challenges when describing the working relationship with the submetro: ${ }^{[10]}$

\section{Well for the municipality helping us, there is a bit of collaboration but not much at all it's not helpful we mainly work with $\mathrm{CHF}$, the water company and the submetro. But what I'm saying is that the submetro it's a challenge, it's very difficult because as a government initiative to get Accra as a millennium city, we were thinking that this intervention from $C H F$ and USAID, there [would] be some speed. But you don't see that, you don't see that coming from the submetro. There is something, I cannot describe. (Interview with LWB member, 14 July 2011)}

This statement illustrates the frustration linked with having to negotiate the complex multiscalar governance landscape, as well as the difficulties of engagement and working with particular entities such as the submetro. Again, akin to the broader participatory governance literature, this begs a question regarding the specific instances for which participation is the key, and those for which broader institutional or governance reform may be more suitable for improved access, accountability, efficiency, or equity goals.

\section{Burden on communities}

LWBs are based on the voluntary work of their members, which echo challenges and concerns raised in the literature with regard to devolving the burden of water management to communities or to certain segments of these populations. One youth representative emphasized the challenges of this voluntary labor for community members:

This board is not paid. It is a volunteer job that we are
doing. It's not being paid and look at me. I'm a young
guy, right. Abandon my jobs and sit in meetings and stuff
like that. It is very challenging. You abandon your work
that you have to do on your [computer] and come sit
here three or four hours discussing issues that wouldbring
this community ahead. But, I've [also] learn[ed] a whole
lot from it not [every] thing that you do [has] to collect
money or something like that. You have to sometime also
volunteer some of your time to do this communal work
and you're pleased to do that. (Interview with LWB
member, 25 July 2011)

We see the importance for any assessment of participatory and adaptive governance approaches to consider the burden of devolution as a central feature of these approaches. To the degree that we expect communities to engage and provide feedback, or to invest time and resources, consideration must also be given to the possibility of compensation, or to the likely uneven and skewed nature of the resulting participation if such compensation is not available.

\section{External influence}

All LWBs investigated as part of this research were established by an agency external to the communities, which may limit their ability to represent community members in a grassroots sense. This raises questions regarding how transformative and truly participatory the LWBs may be as a governance model, at least in their current form. Many of these issues were confirmed in a Community Debrief Session we held in 2012. We gathered representatives from three of Accra's LWBs to discuss the results of this work. Among other issues, the feedback discussion emphasized the reliance on voluntary labor. Community members also made allusions to the strictness of donors. In particular, board members felt limited in their potential to respond to community concerns given the lack of flexibility around funding requirements and donor agendas. Furthermore, the need for communities to commit to rigid multiyear plans offers few opportunities for adjustments and presents significant limits for the adaptive capacity of these schemes. Contrary to the theory of flexible and adaptive governance, reliance on external funding and long-range planning processes meant that communities were, in effect, very limited in their ability to respond to changing conditions. As such, the current framework of Accra's LWBs does not allow ready adaptation to new priorities, even when the situation on the ground has shifted (see Hailey 2001 for a discussion of the influence of external funders in general terms).

\section{Formal and informal participation}

LWBs represent formal institutions for participation in Accra, but as such, they may also circumscribe what is understood as "appropriate" participation. As highlighted by the literature on participatory governance, there is a need to consider other, i.e., informal, modes of engagement. To do so, it is instructive to consider ways that community members engage in decision making related to water use, access, or condition, in short, governance, beyond the remit of the LWBs. We mobilize two examples to consider these types of informal and unsanctioned modes of engagement. 
Our first example is the case of a vendor who split from one of the LWBs, taking over the polytank, i.e., storage tank, that the board had provided. He suggested that the board had not maintained regular water supply for him to sell and, as such, had not upheld its end of the bargain. He also suggested that quarreling with certain members of the board made it difficult to work with them, pointing out the types of challenges that are inevitable with participatory governance (interview with water vendor, 22 July 2011). The board involved in this dispute dismissed the vendor and derided his actions. During interviews, members of the board highlighted that he was no longer a participant in the board's activities. This situation raises interesting questions from a participatory governance perspective. The vendor was clearly still engaged in managing and providing water in the community. He interacted directly with private tanker services and was able to overcome difficulties associated with interruptions in service. However, he was no longer considered a "participant" in a formal sense given his split from the LWB. This example raises important questions regarding the types of involvement that are recognized as "participatory" or considered acceptable. Does the vendor's continuing engagement with water delivery constitute a form of participation, or because he no longer works within the remit of the board, are his activities rather working against the principles of participatory water governance, as some comments by LWB members might suggest?

Our second example concerns the establishment of a "splinter" second board in one of the communities we studied. In part because of political divisions and other challenges among the membership of the first board, a different external organization than the one involved with the original board established a second LWB in the community. In the current situation, both entities question and dismiss the legitimacy of the other board, significantly limiting the efficiency of both boards to fulfill their mandates and their ability to foster inclusive water governance processes in the community (interview with government official involved with LWBs, 12 July 2012). This not only raises questions around how participatory and adaptive water governance systems should be organized and implemented, but also underlines issues with prescribed solutions superimposed by external agencies.

We find that both of these cases challenge simplistic ways of understanding participation and also provide illustrations of the ways that participatory approaches can become overly rigid, excluding other modes of engagement. As participation is increasingly called for and mainstreamed, it becomes difficult, if not impossible, to recognize or validate that which falls outside those dominant frameworks, as with notions of hegemonic understandings in water governance (see Harris et al. 2013). Some of these alternative engagements could, nonetheless, hold transformative potential for community participation and access to water; again, consider the parallels in long-standing work on informal institutions (e.g., Ostrom 1990).

\section{Politics and social power}

Before moving to a discussion, we present one last illustrative example looking more closely at the importance of the broader context in which participatory schemes unfold, or are implemented, including factors such as social power, power dynamics, and politics. We consider the case of Sukura. In the absence of a preselected and formally sanctioned LWB, community members in this district have organized themselves differently to engage the utility (GWCL) in a dialogue. The community worked on a Community Scorecard project to grade the utility for the services the communities receives, and GWCL engaged in a self-assessment of its services. They later met together to discuss discrepancies in the grading and issues affecting the community (interview with National Coalition Against the Privatization of Water activists, 1 July 2011; interview with official from the Coalition of NGOs on Water and Sanitation, or CONIWAS, 20 July 2011). First, even as these types of direct engagement appear promising, again they were facilitated by an external entity, in this case CONIWAS. This again raises questions regarding the influence of actors external to the community. Second, although the community is engaged in water governance processes through the Community Scorecard program, it is interesting to consider the history of its engagement.

Sukura is an in-migrant community, and a majority of its residents are Muslim. In 2001, the community was subjected to police raids twice in the same week, after which community members organized themselves. In the words of one of our key informants: "Some of us began to say no, no, no, we will not allow this. So we began organizing ourselves also to have our own kind of resistance" (interview with Local Action Committee [LAC] member, 1 July 2011). The Integrated Social Development Centre was at the same time organizing its antiprivatization campaign and networked with community leaders from Sukura to facilitate the establishment of an LAC. Water became one of the focal issues of the community group advocating for social change within the neighborhood. The committee later worked with CONIWAS on the Community Scorecard program (interview with LAC member, 1 July 2011). Although engagement clearly can be motivated by a range of considerations, this example points to the broader political context in which community participation in water governance is embedded. Engagement in water decision making and governance was facilitated by the community being compelled to action for other reasons. Through examples such as this one, it is clear that contextual factors and power dynamics between community members, as well as between communities and state authorities, may be important to understand how and why participation might unfold in particular ways.

\section{Discussion}

As presented previously, participatory mechanisms, such as the LWBs implemented in Accra, hold potential for improving water access and fostering more inclusive and adaptive water governance processes. Namely, Accra's LWBs may open up channels for discussions and foster stronger collaborative partnerships between different stakeholders involved with water governance at different scales and in different capacities; extend water access in underserved areas; contribute to reducing nonpayment issues or nonrevenue water of importance for the utility; reduce stress around pricing for community members through the pre-establishment of prices; and contribute to infrastructural development in the communities.

At the same time, these schemes face significant limits. In this sense, elements of our results echo insights from the critical literatures on participation in international development and conservation. Specifically, we find that LWBs may also heighten affordability challenges attributable to prepayment arrangements; 
remain limited in brokering higher levels of connectivity and extended services because of complex bureaucratic procedures enforced at the municipal level; further burden the poor and vulnerable by relying on voluntary labor; do little to foster grassroots participation and answer locally determined needs, because all schemes were implemented by external organizations; fail to recognize various types of participation because of a narrow focus on prescribed participatory mechanisms and formal pathways and institutions; and fail to recognize and take into account the historical, social, and political context into which these mechanisms arise and are implemented.

Furthermore, it is important to note that participation remains somewhat limited among the communities at large. Although we found active community organizations in 3 of the communities studied and other avenues for participation in the other 2, as in the case of Sukura, which we have detailed (see also Peloso 2014 for a discussion on Ashaiman), our survey data report that very few of the residents surveyed in Teshie and Ashaiman presently participate in water management groups or committees, with $86 \%$ of respondents answering "no" to this question. ${ }^{[11]}$ Again, almost all respondents, 99\%, suggested that "no such committees exist," with the exception of 2 respondents in Teshie, despite the existence of an LWB in that community, as discussed previously. The survey data also report that many people would like to participate in water governance; when asked directly if they "wish they could participate more in community meetings," $57 \%$ "strongly agreed" or "agreed" with this statement. Although not exhaustive, this portrait suggests that people are interested in participating in water governance, with an even higher number $(67 \%)$ indicating that they feel they would have something to offer. In both cases, there appears to be an interest or acknowledgement of the importance of participation, but perhaps without knowing the pathways to allow that to happen. Participatory approaches must be mindful of the willingness and desire to participate, and when such a clear interest exists, make pathways available to enable that engagement. However, when the opposite is true, and when communities may be overburdened or unable to commit resources to active engagement, other mechanisms must exist to promote community feedback in a way that nonetheless facilitates institutional learning and adaptive governance.

Furthermore, from a social-ecological perspective, the case study of Accra's LWB illustrates some of the complexities associated with implementing local governance in ways that usefully integrate with other levels and scales of governance, i.e., GWCL or internationally funded NGOs. It provides examples of how these participatory institutions, although "successful" in some senses, also lack adaptive capacities needed from a socialecological perspective, involving, for instance, learning and adaptation across scales drawing on multiple levels of feedback and interaction. For instance, our feedback session elicited comments suggesting that the funding timelines of donor agencies do not allow LWBs to be nimble and respond dynamically to changing community needs and priorities. In this sense, participatory frameworks in Accra, and for urban water governance more generally, must seek out more effective ways to communicate with communities on a regular basis, while also working toward flexible and adaptive mechanisms to incorporate that feedback in governance processes or system design.
At the same time, although participation mechanisms hold clear potential, and are of course desirable on many levels, they must not be taken as a "be-all and end-all" approach to contemporary urban water governance (see also Morinville and Harris 2013 for a related discussion on participation's conceptual limits). In other words, we issue a word of caution with respect to uncritically adopting a focus on participatory mechanisms for adaptive water governance approaches. Failure to do so, we suggest, may result in what scholars have described as a panacea problem (Ostrom 2007, Ostrom and Cox 2010, Pahl-Wostl et al. 2012), whereby participation becomes at once too vague when advocated as a primary focus of urban water governance, and yet too narrow and prescriptive when envisioned in the form of LWBs or other particular mechanisms such as the ones examined in our case study. We suggest that it is most useful, and appropriate, to rather consider the manifold opportunities and limits of any participatory governance model as applied to a particular context or locale. Furthermore, we also echo recent calls regarding the need for adaptive water governance to attentively consider questions of social power (Armitage 2008, Pahl-Wostl 2009, PahlWostl et al. 2011, Bakker and Morinville 2013). Adaptive governance is, after all, attuned to outcomes and responds accordingly. In this same way, we think more nuanced appreciation of the limits and opportunities of specific governance mechanisms might enable refinement, attunement, and critical reflection.

\section{CONCLUSIONS}

This article has sought to shed light on the limits of participatory approaches to urban water governance. Our interest in doing so is to consider ways that participation might most usefully help to foster sustainability of resources or the resilience of urban socialecological systems. Although Accra is not located in a water scarce region per se, the metropolitan area faces considerable quotidian water shortages likely to be heightened by climate change, urbanization, and population increases already underway (Douglas et al. 2008). Participation is critical to move toward more efficient and equitable management of this limited resource and its long-term sustainability. We see clear evidence in the previous discussion of the ways that participation may offer partial responses to issues of resources sharing, limiting wastage, or unaccounted for water, or perhaps ways that LWBs can facilitate smooth interactions between the utility and the community or help to monitor and respond to leakages or other infrastructural failures. Furthermore, although participation for sanitation and wastewater concerns was not central for us, lessons from LWBs for water distribution may help to inform a number of sanitation initiatives that are currently unfolding across Accra, some through the LWB framework. This is also an issue where considerable equity, health, ecological, and broader sustainability concerns are at stake.

We have highlighted a range of issues that suggest that there is fertile ground for participation in Accra's most underserved communities. Our survey respondents clearly indicate a desire to be involved and the partial successes of the LWBs to date also speak to the potential importance of greater participatory governance in the water sector. As such, we have argued that LWBs, as one of the most visible mechanisms for participatory engagement of these communities at present, have clear opportunities. However, we have also highlighted what we observe 
as considerable limits, whether for equity, accountability, efficiency, or the broader adaptive and learning goals required for adaptive and resilient socio-hydrologic systems. In line with this, we have also detailed some conceptual issues related to the ways in which participation is often circumscribed to formal modes of engagement. We find it important to question what counts as participation and what modes of engagement are left out by such frameworks. Careful attention to the opportunities and limits of different participatory frameworks is precisely the sort of work required to avoid panacea thinking and work toward revamping our toolkit toward fostering more sustainability and resilience in urban water governance over the long term.

${ }^{[1]}$ This echoes feminist scholars who have long been calling for an appreciation of the "informal" or "alternative" spheres of engagement (e.g., McEwan 2000, Staeheli et al. 2004).

${ }^{[2]} \mathrm{CHF}$ is one of $\sim 65$ NGOs working on water- and sanitationrelated issues in Ghana (interview, 20 July 2011). Its core mission involves community-based water and sanitation solutions for informal and slum settlements (CHF-Ghana, http://www. chfinternationalghana.org/).

[3] "Improved" sources include public taps, standpipe, or rainwater sources; whereas "unimproved" sources include tanker trucks, surface water, or unprotected dug wells (WHO/UNICEF 2012).

${ }^{[4]}$ L. M. Harris, J. A. Goldin, A. Darkwah, and UBC EDGES Research Collaborative, unpublished manuscript. This survey was conducted with the support of the Center for International Governance Innovation. Note that a parallel survey was also implemented in two settlements of Cape Town, South Africa (Philippi and Khayelitsha), although we do not mobilize data from South Africa.

${ }^{[5]}$ UN-HABITAT (2006) defines a slum household as a group of individuals living under the same roof in an urban area who lack one or more of the following: (1) durable housing of a permanent nature that protects against extreme climate conditions; (2) sufficient living space, which means not more than three people sharing the same room; (3) easy access to safe water in sufficient amounts at an affordable price; (4) access to adequate sanitation in the form of a private or public toilet shared by a reasonable number of people; and (5) security of tenure that prevents forced evictions.

[6] Boards under $\mathrm{CHF}$ administration are called "Water and Sanitation Boards" (WSBs). To limit confusion, we maintain the use of LWB throughout, given their shared function, particularly with respect to citizen engagement.

[7] Polytanks are large water storage tanks made of plastic, i.e., polyethylene. They are common for vending and also among wealthier households seeking to avoid problems associated with supply.

${ }^{[8]}$ The boreholes were drilled but not yet functioning at the time of conducting fieldwork.

${ }^{[9]}$ The LWB typically collects only the money for the water it sells directly. Bills to consumers enjoying a direct connection to the pipe network must be paid to the utility directly.

${ }^{[10]}$ There are currently 13 submetropolitan governance units in Accra, which together make up the Accra Metropolitan Assembly, the entity responsible for approving construction, including digging of new water or sewage infrastructure.

${ }^{[11]}$ Compared, for instance, to the $77 \%$ who report that they participate in church activities.
Responses to this article can be read online at: http://www.ecologyandsociety.org/issues/responses. php/6623

\section{Acknowledgments:}

We would like to thank colleagues from ICGC-UWC-UBC International WaTERS research network, Corin de Freitas, and three anonymous reviewers for helpful comments on earlier versions. A portion of the content presented in this paper has been published previously in the following book chapter: Morinville, C., and L. M. Harris. 2013. Participation's limits: tracing the contours of participatory water governance in Accra, Ghana. Pages 216-231 in L. M. Harris, J. A. Goldin, and C. Sneddon, editors. Contemporary water governance in the Global South: scarcity, marketization and participation. Routledge, London, UK.

\section{LITERATURE CITED}

Adank, M., B. Darteh, P. Moriarty, H. Osei-Tutu, D. Assan, and D. van Rooijen. 2011. Towards integrated urban water management in the Greater Accra Metropolitan Area: current status and strategic directions for the future. Switch/RCN Ghana, Accra, Ghana.

Agarwal, B. 2001. Participatory exclusions, community forestry, and gender: an analysis for South Asia and a conceptual framework. World Development 29:1623-1648. http://dx.doi. org/10.1016/S0305-750X(01)00066-3

Agarwal, B. 2010. Gender and green governance: the political economy of women's presence within and beyond community forestry. Oxford University Press, Oxford, UK. http://dx.doi. org/10.1093/acprof:oso/9780199569687.001.0001

Ahmad, Q. K. 2003. Towards poverty alleviation: the water sector perspectives. International Journal of Water Resources Development 19(2):263-277. http://dx.doi.org/10.1080/07900620$\underline{32000089356}$

Ainuson, K. G. 2010. Urban water politics and water security in disadvantaged urban communities in Ghana. African Studies Quarterly 11(4):59-82.

Armitage, D. 2008. Governance and the commons in a multi-level world. International Journal of the Commons 2:7-32.

Armitage, D., F. Berkes, A. Dale, E. Kocho-Schellenberg, and E. Patton. 2011. Co-management and the co-production of knowledge: learning to adapt in Canada's Arctic. Global Environmental Change 21(3):995-1004. http://dx.doi.org/10.1016/ j.gloenvcha.2011.04.006

Armitage, D., M. Marschke, and R. Plummer. 2008. Adaptive comanagement and the paradox of learning. Global Environmental Change 18(1):86-98. http://dx.doi.org/10.1016/j.gloenvcha.2007.07.002

Bakker, K., and C. Morinville. 2013. The governance dimension of water security: a review. Philosophical Transactions of the Royal Society A 371:20130116. http://dx.doi.org/10.1098/rsta.2013.0116

Barnes, J. 2013. Who is a water user? The politics of gender in Egypt's water user associations. Pages 185-198 in L. M. Harris, J. 
A. Goldin, and C. Sneddon, editors. Contemporary water governance in the global South: scarcity, marketization and participation. Routledge, London, UK.

Berkes, F., J. Colding, and C. Folke, editors. 2003. Navigating social-ecological systems: building resilience for complexity and change. Cambridge University Press, Cambridge, UK. http://dx. doi.org/10.1017/CBO9780511541957

Cleaver, F. 2001. Institutions, agency and the limitations of participatory approaches to development. Pages 36-55 in B. Cooke and U. Kothari, editors. Participation: the new tyranny? Zed Books, London, UK.

Cooke, B., and U. Kothari. 2001. Participation: the new tyranny? Zed Books, London, UK.

Cumming, G. S., D. H. M. Cumming, and C. L. Redman. 2006. Scale mismatches in social-ecological systems: causes, consequences, and solutions. Ecology and Society 11(1): 14. [online] URL: http://www.ecologyandsociety.org/vol11/iss1/ art14l

Dietz, T., E. Ostrom, and P. C. Stern. 2003. The struggle to govern the commons. Science 302:1907-1912. http://dx.doi.org/10.1126/ $\underline{\text { science. } 1091015}$

Douglas, I., K. Alam, M. Maghenda, Y. Mcdonnell, L. Mclean, and J. Campbell. 2008. Unjust waters: climate change, flooding and the urban poor in Africa. Environment and Urbanization 20 (1):187-205. http://dx.doi.org/10.1177/0956247808089156

Dublin Principles. 1992. The Dublin Statement on Water and Sustainable Development. [online] URL: http://www.wmo.int/ pages/prog/hwrp/documents/english/icwedece.html

Few, R., K. Brown, and E. L. Tompkins. 2007. Public participation and climate change adaptation: avoiding the illusion of inclusion. Climate Policy 7(1):46-59. http://dx.doi.org/10.3763/ cpol.2007.0704

Folke, C., S. Carpenter, T. Elmqvist, L. Gunderson, C. Holling, and B. Walker. 2002. Resilience and sustainable development: building adaptive capacity in a world of transformations. AMBIO 31(5):437-440. http://dx.doi.org/10.1579/0044-7447-31.5.437

Folke, C., T. Hahn, P. Olsson, and J. Norberg. 2005. Adaptive governance of social-ecological systems. Annual Review of Environment and Resources 30:441-473. http://dx.doi.org/10.1146/ annurev.energy.30.050504.144511

Goldin, J. A. 2010. Water policy in South Africa: trust and knowledge as obstacles to reform. Review of Radical Political Economics 42(2):195-212. http://dx.doi.org/10.1177/0486613410368496

Goldin, J. A. 2013. The participatory paradigm: anathema, praise and confusion. Pages 179-184 in L. M. Harris, J. A. Goldin, and C. Sneddon, editors. Contemporary water governance in the global South. Routledge, London, UK.

Government of Ghana. 2011.2010 Population and housing census: provisional results: summary of findings. Ghana Statistical Services, Accra, Ghana.

Gunderson, L. H., S. R. Carpenter, C. Folke, P. Olsson, and G. D. Peterson. 2006. Water RATs (resilience, adaptability, and transformability) in lake and wetland social-ecological systems.
Ecology and Society 11(1): 16. [online] URL: http://www. ecologyandsociety.org/vol11/iss1/art16/

Hailey, J. 2001. Beyond the formulaic: process and practice in South Asian NGOs. Pages 88-101 in B. Cooke and U. Kothari, editors. Participation: the new tyranny? Zed Books, London, UK.

Harris, L. M. 2005. Negotiating inequalities: democracy, gender, and politics of difference in water user groups in southeastern Turkey. Pages 185-200 in F. Adaman and M. Arsel, editors. Environmentalism in Turkey: between democracy and development? Ashgate, Aldershot, UK.

Harris, L. M. 2009. Gender and emergent water governance: comparative overview of neoliberalized natures and gender dimensions of privatization, devolution, and marketization. Gender, Place \& Culture: A Journal of Feminist Geography 16 (4):387-408. http://dx.doi.org/10.1080/09663690903003918

Harris, L. M., J. A. Goldin, and C. Sneddon, editors. 2013. Contemporary water governance in the global South. Routledge, London, UK.

Hickey, S., and G. Mohan. 2004. Participation: from tyranny to transformation, exploring new approaches to participation in development. Zed Books, London, UK.

Holling, C. S., editor. 1978. Adaptive environmental assessment and management. John Wiley and Sons, New York, New York, USA.

Holling, C. S., and G. K. Meffe. 1996 Command and control and the pathology of natural resource management. Conservation Biology 10(2):328-337. http://dx.doi.org/10.1046/

j.1523-1739.1996.10020328.x

Huitema, D., E. Mostert, W. Egas, S. Moellenkamp, C. PahlWostl, and R. Yalcin. 2009. Adaptive water governance: assessing the institutional prescriptions of adaptive (co-)management from a governance perspective and defining a research agenda. Ecology and Society 14(1): 26. [online] URL: http://www.ecologyandsociety. org/vol14/iss1/art26/

Huntjens, P., C. Pahl-Wostl, B. Rihoux, M. Schlüter, Z. Flachner, S. Neto, R. Koskova, C. Dickens, and I. Nabide Kiti. 2011. Adaptive water management and policy learning in a changing climate: a formal comparative analysis of eight water management regimes in Europe, Africa and Asia. Environmental Policy and Governance 21(3):145-163. http://dx.doi.org/10.1002/ eet. 571

Kesby, M. 2005. Retheorizing empowerment-through-participation as a performance in space: beyond tyranny to transformation. Signs: Journal of Women in Culture and Society 30(4):2037-2065. http://dx.doi.org/10.1086/428422

Kofinas, G. 2005. Caribou hunters and researchers at the comanagement interface emergent dilemmas and the dynamics of legitimacy in power sharing. Anthropologica 47(2):179-196.

Lebel, L., J. M. Anderies, B. Campbell, C. Folke, S. HatfieldDodds, T. P. Hughes, and J. Wilson. 2006. Governance and the capacity to manage resilience in regional socio-ecological systems. Ecology and Society 11(1): 19. [online] URL: http://www. ecologyandsociety.org/vol11/iss1/art19/ 
Lee, K. N. 1999. Appraising adaptive management. Conservation Ecology 3(2): 3. [online] URL: http://www.consecol.org/vol3/iss2/ $\underline{\operatorname{art} 3 /}$

Lim, B., E. Spanger-Siegfried, I. Burton, E. Malone, and S. Huq. 2004. Adaptation policy frameworks for climate change: developing strategies, policies, and measures. United Nations Development Programme, Cambridge University Press, Cambridge, UK.

McEwan, C. 2000. Engendering citizenship: gendered spaces of democracy in South Africa. Political Geography 19:627-651. http://dx.doi.org/10.1016/S0962-6298(00)00009-3

McLain, R. J., and R. G. Lee. 1996. Adaptive management: promises and pitfalls. Environmental Management 20(4):437-448. http://dx.doi.org/10.1007/BF01474647

Morales, M., and L. Harris. In press. Using subjectivity and emotion to reconsider participatory natural resource management. World Development.

Morinville C., and L. M. Harris. 2013. Participation's limits: tracing the contours of participatory water governance in Accra, Ghana. Pages 216-231 in L. M. Harris, J. A. Goldin, and C. Sneddon, editors. Contemporary water governance in the global South: scarcity, marketization and participation. Routledge, London, UK.

Nadasdy, P. 2003. Hunters and bureaucrats: power, knowledge, and aboriginal-state relations in the southwest Yukon. The University of British Columbia Press, Vancouver, British Columbia, Canada.

Nadasdy, P. 2005. The anti-politics of TEK: the institutionalization of co-management discourse and practice. Anthropologica 47(2):215-232.

Nadasdy, P. 2007. Adaptive co-management and the gospel of resilience. Pages 208-227 in D. Armitage, F. Berkes, N. Doubleday, editors. Adaptive co-management: collaboration, learning, and multilevel governance. The University of British Columbia Press, Vancouver, British Columbia, Canada.

Olsson, P., C. Folke, and F. Berkes. 2004. Adaptive comanagement for building resilience in social-ecological systems. Environmental Management 34(1):75-90. http://dx.doi.org/10.1007/s00267-003-0101-7

Olsson, P., L. H. Gunderson, S. R. Carpenter, P. Ryan, L. Lebel, C. Folke, and C. S. Holling. 2006. Shooting the rapids: navigating transitions to adaptive governance of social-ecological systems. Ecology and Society 11(1): 18. [online] URL: http://www. ecologyandsociety.org/vol11/iss1/art18/

O'Reilly, K., and R. Dhanju. 2012. Hybrid drinking water governance: community participation and ongoing neoliberal reforms in rural Rajasthan, India. Geoforum 43(3):623-633. http:// dx.doi.org/10.1016/j.geoforum.2011.12.001

Ostrom, E. 1990. Governing the commons: the evolution of institutions for collective action. Cambridge University Press, Cambridge, UK. http://dx.doi.org/10.1017/CBO9780511807763

Ostrom, E. 2007. A diagnostic approach for going beyond panaceas. Proceedings of the National Academy of Sciences of the United States of America 104(39):15181-15187. http://dx.doi. org/10.1073/pnas.0702288104
Ostrom, E., and M. Cox. 2010. Moving beyond panaceas: a multitiered diagnostic approach for social-ecological analysis. Environmental Conservation 37(4):451-463. http://dx.doi.org/10.1017/ S0376892910000834

Pahl-Wostl, C. 2009. A conceptual framework for analysing adaptive capacity and multi-level learning processes in resource governance regimes. Global Environmental Change 19(3):354-365. http://dx.doi.org/10.1016/j.gloenvcha.2009.06.001

Pahl-Wostl, C., L. Lebel, C. Knieper, and E. Nikitina. 2012. From applying panaceas to mastering complexity: toward adaptive water governance in river basins. Environmental Science \& Policy 23:24-34. http://dx.doi.org/10.1016/j.envsci.2012.07.014

Pahl-Wostl, C., C. Nilsson, J. Gupta, and K. Tockner. 2011. Societal learning needed to face the water challenge. AMBIO 40 (5):549-553. http://dx.doi.org/10.1007/s13280-011-0149-1

Parkes, M. W., K. E. Morrison, M. J. Bunch, L. K. Hallström, R. C. Neudoerffer, H. D. Venema, and D. Waltner-Toews. 2010. Towards integrated governance for water, health and socialecological systems: the watershed governance prism. Global Environmental Change 20(4):693-704. http://dx.doi.org/10.1016/ j.gloenvcha.2010.06.001

Peloso, M. M. 2014. Navigating water access and governance in peri-urban Ashaiman, Ghana: a cast study. Thesis. The University of British Columbia, Vancouver, British Columbia, Canada.

Ribot, J. 2002. Democratic decentralization of natural resources: instituting popular participation. World Resources Institute, Washington, D.C., USA.

Schreiner, B., N. Mohapi, and B. Van Koppen, 2004. Washing away poverty: water, democracy and gendered poverty eradication in South Africa. Natural Resources Forum 28(3):171-178. http:// dx.doi.org/10.1111/j.1477-8947.2004.00086.x

Secretariat of the International Conference on Freshwater. 2001. Bonn recommendations for actions: water - a key to sustainable development. Secretariat of the International Conference on Freshwater, Bonn, Germany. [online] URL: http://www.un.org/ esa/sustdev/sdissues/water/BonnConferenceReport.pdf

Spaeder, J. 2005. Co-management in a landscape of resistance: the political ecology of wildlife management in western Alaska. Anthropologica 47(2):165-178.

Staeheli, L. A., E. Kofman, and L. Peake. 2004. Mapping women, mapping politics: feminist perspectives on political geography. Routledge, London, UK.

Tompkins, E. L., and W. N. Adger. 2004. Does adaptive management of natural resources enhance resilience to climate change? Ecology and Society 9(2): 10. [online] URL: http://www. ecologyandsociety.org/vol9/iss2/art10/

United Nations Economic Commission for Europe (UNECE). 1998. Public participation in decision-making and access to justice in environmental matters done at Aarhus, Denmark, on 25 June 1998. UNECE, Geneva, Switzerland. [online] URL: http://www. unece.org/fileadmin/DAM/env/pp/documents/cep43e.pdf 
United Nations Human Settlements Programme (UNHABITAT). 2006. State of the world's cities 2006/7. UNHABITAT, Nairobi, Kenya.

Walker, P. A. 1999. Democracy and environment: congruencies and contradictions in southern Africa. Political Geography 18 (3):257-284. http://dx.doi.org/10.1016/S0962-6298(98)00102-4

Westerhoff, L., and B. Smit. 2009. The rains are disappointing us: dynamic vulnerability and adaptation to multiple stressors in the Afram Plains, Ghana. Mitigation and Adaptation Strategies for Global Change 14(4):317-337. http://dx.doi.org/10.1007/s11027-008-9166-1

The World Bank. 2014. Urban water project. [online] URL: http:// www.worldbank.org/projects/P056256/urban-water-project?lang= en\&tab $=$ overview

World Health Organization (WHO)/United Nations International Children's Emergency Fund (UNICEF). 2012. Joint Monitoring Programme (JMP) for water supply and sanitation [table]. WHO, Geneva Switzerland; UNICEF, Geneva, Switzerland. [online] URL: http://www.wssinfo.org/data-estimates/table/

Wutich, A., and K. Ragsdale. 2008. Water insecurity and emotional distress: coping with supply, access, and seasonal variability of water in a Bolivian squatter settlement. Social Science \& Medicine 67(12):2116-2125. http://dx.doi.org/10.1016/ j.socscimed.2008.09.042

Zwarteveen, M., P. Udar, and J. Delgado. 2010. Gendered dynamics of participation in water management in Nepal and Peru: revisiting the linkages between membership and power. Pages 69-92 in K. Berry and E. Mollard, editors. Social participation in water governance and management: critical and global perspectives. Earthscan, London, UK. 